\title{
Isolated Horner's Syndrome Secondary To Rhinosinusitis: A Case Report And Literature Review
}

\author{
Jamir Pitton Rissardo ${ }^{1,2^{*}}$ (D), Ana Letícia Fornari Caprara ${ }^{1,2}$, Juliana Oliveira Freitas Silveira ${ }^{1}$ and \\ Paulo Gilberto Medeiros Jauris ${ }^{1}$
}

\begin{abstract}
Background: Horner's syndrome (HS) is characterized by unilateral ptosis, ipsilateral miosis with normally reactive pupil, and in some cases, ipsilateral facial anhidrosis.

Case presentation: We report an adult male presenting with ptosis. Neurological examination revealed ptosis and miosis in the right eye. Anhidrosis was not observed, and the patient did not complain about it. Laboratory tests were within normal limits. He had searched a general practitioner because of purulent nasal discharge, nasal obstruction, and anosmia. He was diagnosed with acute rhinosinusitis. Symptomatic treatment was started. The subject had full recovery of the nasal symptoms, but his right upper eyelid was drooping progressively. In the follow-up, after the third month, the patient was recovering from ptosis and miosis. In 1 year, the ptosis was minor with less than $1 \mathrm{~mm}$ and miosis was no more observed.

Discussion: A few cases of HS secondary to a sinus infection have been reported in the literature. To the authors' knowledge, there are only two case reports of individuals who developed sinusitis and Horner's syndrome. The present case is the first to present isolated HS features. Our report suggests that sinusitis should be listed as a probable cause of isolated Horner's syndrome. Moreover, patients presenting with this presentation probably have a good prognosis.
\end{abstract}

Keywords: Horner syndrome, Sinusitis, Ptosis, Miosis, Anhidrosis

\section{Background}

Horner's syndrome (HS) is characterized by unilateral ptosis, ipsilateral miosis with normally reactive pupil, and in some cases, ipsilateral facial anhidrosis [1]. This constellation of symptoms is the result of damage throughout the ipsilateral oculosympathetic pathway, which could be caused by lesions that range from benign to serious [2]. In this context, a few cases of HS secondary to a sinus infection have been reported in the literature. To the authors' knowledge, there are only two case reports of individuals who developed sinusitis and Horner's syndrome $[3,4]$. But, the present case is probably the first to present with isolated HS features.

\footnotetext{
* Correspondence: jamirrissardo@gmail.com

'Neurology Department, Federal University of Santa Maria, Rua Roraima, Santa Maria, Rio Grande do Sul, Brazil

${ }^{2}$ Medicine Department, Federal Univeristy of Santa Maria, Rua Roraima, Santa Maria, Rio Grande do Sul, Brazil
}

\section{Springer Open}

(c) The Author(s). 2020 Open Access This article is distributed under the terms of the Creative Commons Attribution 4.0 International License (http://creativecommons.org/licenses/by/4.0/), which permits unrestricted use, distribution, and reproduction in any medium, provided you give appropriate credit to the original author(s) and the source, provide a link to the Creative Commons license, and indicate if changes were made.
A 40-year-old male presenting with ptosis was admitted to our hospital. He was a previously healthy farmer, and his family history was negative for neurological diseases. The neurological examination revealed ptosis and miosis in the right eye. The degree of anisocoria was more visible in the dark than in light, and a dilation lag was observed. Anhidrosis was not observed, and the patient did not complain about it. The fundoscopy showed normal color, deep excavations, blood vessels, and the optic discs with clear borders. Laboratory tests were within normal limits. A cranial computed tomography (CT) scan (Aquillion 64, Toshiba/Canon, USA), a brain magnetic resonance imaging (Signa HDx Series 1.5 Tesla, General Eletrics, USA), a chest CT scan (Aquillion 64, Toshiba/Canon, USA), and a CT angiography (Integris 
Allura, Philips, Netherlands) of the head-neck were normal.

On further questioning, the patient stated that he had searched a general practitioner about 1 month before the admission. He had experienced purulent nasal discharge, nasal obstruction, and anosmia; no headache was reported. He was diagnosed with acute rhinosinusitis. Analgesic, saline nasal irrigation, intranasal glucocorticoids, and amoxicillin-clavulanate $500 \mathrm{mg} / 125 \mathrm{mg}$ orally tid over 7 days were started. The subject had full recovery of the nasal symptoms, but his right upper eyelid was drooping progressively.

Pharmacological tests in the patient's pupils were done to evaluate the possible Horner's syndrome. Instillation of two drops of cocaine $10 \%$ was done in both eyes. One hour after, the left pupil dilated more than the right pupil, and the anisocoria increased $2 \mathrm{~mm}$ after the cocaine administration. One week after, the instillation of $1 \%$ hydroxyamphetamine was done in the subject's eyes. The left pupil dilated and the right pupil did not. The anisocoria increased to $1.5 \mathrm{~mm}$.

In the follow-up, after the third month, the patient was recovering from ptosis and miosis. In 1 year, the ptosis was minor with less than $1 \mathrm{~mm}$ and miosis was no more observed. A new pharmacological test was attempted in both pupils, and the result was normal.

\section{Discussion}

Rhinosinusitis (RS), also known as sinusitis, is characterized by the inflammation in the nasal cavity and paranasal sinus [5]. The most frequent etiology of acute RS is a viral infection associated with the common cold, but bacterial infections can occur [6]. The clinical manifestations of acute RS are purulent nasal drainage, nasal obstruction, facial pain/pressure/fullness, anosmia, ear fullness, cough, and headache [6]. Imaging studies only need to be requested when a complication is highly suspected. In this way, the management in the majority of the cases is only symptomatic and can be done with analgesics, saline irrigation, and intranasal glucocorticoids, generally with resolution in days [7].

Horner's syndrome (HS) is caused by damage anywhere throughout the sympathetic pathway of the head [2]. This oculosympathetic circuit is formed by three neurons that are called first-order (hypothalamospinal tract), second-order (preganglionic), and third-order (postganglionic) [8]. In this context, this syndrome can be divided among the neuron that is affected to conduct

Table 1 Case reports of HS after rhinosinusitis

\begin{tabular}{|c|c|c|c|c|}
\hline References & & $\begin{array}{l}\text { Turner and } \\
\text { colleagues }\end{array}$ & $\begin{array}{l}\text { Käcker and } \\
\text { colleagues }\end{array}$ & $\begin{array}{l}\text { Present } \\
\text { case }\end{array}$ \\
\hline Sex/age (years) & & $M / 24$ & $\mathrm{NR} / 62$ & $\mathrm{M} / 40$ \\
\hline Comorbidities & & NR & No & No \\
\hline \multirow[t]{6}{*}{$\begin{array}{l}\text { Horner's syndrome } \\
\text { characteristics }\end{array}$} & $\begin{array}{l}\text { Days since } \\
\text { sinusitis till HS }\end{array}$ & $3 d$ & $10 d$ & $15 d$ \\
\hline & Ptosis & Yes & Yes & Yes \\
\hline & Miosis & Yes & Yes & Yes \\
\hline & Anhidrosis & Yes & NR & No \\
\hline & $\begin{array}{l}\text { Pharmacological } \\
\text { tests }\end{array}$ & No & No & Yes \\
\hline & Neuroimages & $\begin{array}{l}\text { MRA, MRV, and } \\
\text { brain MRI }\end{array}$ & $\begin{array}{l}\text { MRA, CT scan, } \\
\text { and Brain MRl }\end{array}$ & $\begin{array}{l}\mathrm{CT} \text { angiography, } \\
\text { brain MRI }\end{array}$ \\
\hline $\begin{array}{l}\text { Symptoms probably } \\
\text { not directly associated } \\
\text { with HS or rhinosinusitis }\end{array}$ & & $\begin{array}{l}\text { Sharp right } \\
\text { supraorbital pain }\end{array}$ & $\begin{array}{l}\text { Third cranial } \\
\text { nerve palsy }\end{array}$ & No \\
\hline \multirow[t]{2}{*}{ Sinusitis features } & Location & $\begin{array}{l}\text { Ethmoid and } \\
\text { frontal sinus }\end{array}$ & Sphenoidal sinus & Unspecified \\
\hline & Management & Clarithromycin & $\begin{array}{l}\text { Surgical drainage, } \\
\text { ceftriaxone, } \\
\text { metronidazole, } \\
\text { sulfamethoxazole } \\
\text { trimethoprim }\end{array}$ & $\begin{array}{l}\text { Analgesic, saline } \\
\text { nasal irrigation, } \\
\text { intranasal } \\
\text { glucocorticoids, } \\
\text { and amoxicillin- } \\
\text { clavulanate }\end{array}$ \\
\hline Follow-up & & $\begin{array}{l}\text { Full recovery } \\
2 \text { days }\end{array}$ & $\begin{array}{l}\text { Full recovery of } \\
\text { symptoms } 4 \\
\text { weeks later. }\end{array}$ & $\begin{array}{l}\text { The patient } \\
\text { remained with } \\
\text { mild symptoms } \\
\text { after } 1 \text { year. }\end{array}$ \\
\hline
\end{tabular}


a better methodological approach for the diagnostic evaluation.

The clinical symptoms associated with HS are miosis, ptosis, and anhidrosis [2]. These findings have some particularities: miosis is better evaluated in the dark when the degree of anisocoria increases; ptosis is mild because it occurs as a result of Muller's muscle paralysis; anhidrosis is only found in lesions of the first and second order neurons $[2,8]$.

HS secondary to sinus infection was rarely reported in the literature. We identified two cases published in English, and we compared it with the present case (Table 1) $[3,4]$. Nevertheless, the present case was the first to describe a subject with isolated HS after a rhinosinusitis episode. The literature search was performed in Embase, Google Scholar, Lilacs, MEDLINE, Scielo, and ScienceDirect, on a set of terms that included sinusitis, sinus inflammation, and Horner's syndrome.

The studies of Turner and colleagues and Käcker and colleagues presented individuals with unusual symptoms of RS or HS. In the case of Turner, the subject had a single acute supraorbital pain that lasted for at least 3 days and lacrimation was present [3]. These symptoms are commonly found in patients with cluster headache [9, 10]. Also, their patient presented anhidrosis, a clinical feature that is not found in individuals with lesion in the third neuron of the oculosympathetic pathway, which is the best physiopathological explanation for isolated HS associated with sinusitis $[2,3]$. Thus, their report probably described an individual with sinusitis that triggered cluster headaches associated with HS; in this way, the HS in their study was probably not directly associated with sinusitis [2, 3]. However, the study of Turner and colleagues did not describe the follow-up of the patient for a better evaluation of the diagnosis.

Another important fact in the study of Käcker and colleagues is that the individual had sinusitis, which might have triggered HS and oculomotor nerve palsy [4]. In this context, this presentation could be described as, which is characterized by unilateral HS associated with ipsilateral sensory and/or motor abnormalities in the distribution of the 5th cranial nerve fibers [11]. In 1962, Boniuk and Shelzinger classified groups of this rare entity, and the patient of Käcker and colleagues is probably in the group I, which is characterized by oculosympathetic paresis with trigeminal nerve and parasellar nerve involvement [12]. Therefore, the case of Käcker and colleagues probably described an individual with sphenoid sinusitis that triggered this uncommon neurological disorder $[4,12]$. However, this presentation was first reported in the literature by Boniuk and Schlezinger in the frontal and maxillary sinusitis [12].

The isolated HS associated with sinusitis of our case probably occurred with the same pathological mechanism as Raeder syndrome already reported in other sinus infections [13]. This syndrome first affects the third neuron of the oculosympathetic pathway, which arises from the superior cervical ganglion and enters the skull vault bordering the internal carotid artery into the cavernous sinus [2]. After, these sympathetic fibers leave the carotid artery, travel with abducens nerve, and then go with the ophthalmic division of the fifth cranial nerve to enter the orbit through the superior orbital fissure [2]. In this way, our case probably represents an incomplete Raeder syndrome that only affected the third-order neuron. Therefore, we hypothesized that the inflammation caused by sinusitis might have involved only the distal part of the carotid artery bifurcation since facial sweating was not observed in our subject.

In sum, our report suggests that sinusitis should be listed as a probable cause of isolated Horner's syndrome. Moreover, patients presenting with this presentation probably have a good prognosis.

\section{Acknowledgements}

Not applicable.

\section{Authors' contributions}

JPR carried out the literature search, review, and manuscript preparation. ALFC, JOFS, and PGMJ performed the manuscript editing and collected the clinical data. All authors read and approved the final manuscript.

\section{Funding}

None to declare.

\section{Availability of data and materials}

The datasets supporting the conclusions of this article are included in the article.

Machines used in the study were computed tomography: Aquillion 64, Toshiba/Canon, USA; Angiography: Integris Allura, Philips, Netherlands; and magnetic resonance imaging: Signa HDx Series 1.5 Tesla, General Electrics, USA.

\section{Ethics approval and consent to participate}

We confirm that ethical clearance was not required for publication of this case report. Written informed consent was obtained from the patient.

\section{Consent for publication}

Written informed consent was obtained from the patient for publication of this case report and accompanying images.

\section{Competing interests}

The authors declare that they have no competing interests.

Received: 3 September 2019 Accepted: 18 February 2020 Published online: 27 February 2020

\footnotetext{
References

1. Kisch B. Horner's syndrome, An American Discovery. Bull Hist Med. 1951;25: 284.

2. Kanagalingam S, Nr M. Horner Syndrome: Clinical Perspectives. Eye Brain. 2015;7:35.

3. Turner I, Newman S, Agrillo T. Painful postganglionic Horners syndrome caused by Ethmoid sinusitis. Headache. 2004;44:816-7.

4. Käcker C, Wagner F, Caversaccio M, Anschuetz L. Horner syndrome as complication of acute sphenoid sinusitis. Case Rep Neurol. 2019;11:112-6.

5. Gwaltney JM, Scheld WM, Sande MA, Sydnor A. The microbial etiology and antimicrobial therapy of adults with acute community-acquired sinusitis: a
} 
fifteen-year experience at the University of Virginia and review of other selected studies. J Allergy Clin Immunol. 1992;90:457-62.

6. Rosenfeld RM, Piccirillo JF, Chandrasekhar SS, Brook I, Ashok Kumar K, Kramper M, et al. Clinical practice guideline (update): adult sinusitis. Otolaryngol Head Neck Surg. 2015;152:1-39.

7. Chow AW, Benninger MS, Brook I, Brozek JL, Goldstein EJ, Hicks LA, et al, Idsa clinical practice guideline for acute bacterial rhinosinusitis in children and adults. Clin Infect Dis. 2012;54:72-112.

8. Ettinger $\mathrm{E}$, Wyatt $\mathrm{H}$, London R. Anisocoria. Variation and clinical observation with different conditions of illumination and accommodation. Invest Ophthalmol Vis Sci. 1991;32:501-9.

9. Woodruff G, Buncic JR, Morin JD. Horner's syndrome in children. J Pediatr Ophthalmol Strabismus. 1988;25:40-4.

10. George N, Gonzalez G, Hoyt C. Does Horner's syndrome in infancy require investigation? Br J Ophthalmol. 1998;82:51-4.

11. Raeder J. "Paratrigeminal" Paralysis Of Oculo-Pupillary Sympathetic. Brain. 1924;47:149-58

12. Boniuk M, Schlezinger NS. Raeder's paratrigeminal syndrome. Am J Ophthalmol. 1962;54:1074-84.

13. Dewitt JD, Thompson SW. Raeder's syndrome: a case with maxillary sinusitis. Headache. 1975;15:91-5.

\section{Publisher's Note}

Springer Nature remains neutral with regard to jurisdictional claims in published maps and institutional affiliations.

\section{Submit your manuscript to a SpringerOpen ${ }^{\circ}$ journal and benefit from:}

- Convenient online submission

- Rigorous peer review

- Open access: articles freely available online

High visibility within the field

- Retaining the copyright to your article

Submit your next manuscript at $\boldsymbol{\nabla}$ springeropen.com 